\title{
A new species of Pseudocercospora on Encephalartos barteri from Benin
}

\author{
Meswaet $\mathbf{Y}^{1}$, Mangelsdorff $\mathbf{R}^{1}$, Yorou NS ${ }^{2}$ and Piepenbring $\mathbf{M}^{1}$ \\ ${ }^{1}$ Institute of Ecology, Evolution and Diversity, Faculty of Biosciences, Goethe University Frankfurt am Main, \\ Biologicum, Max-von-Laue-Str. 13, 60439 Frankfurt am Main, Germany \\ ${ }^{2}$ Faculty of Agronomy, University of Parakou, BP 123 Parakou, Benin
}

Meswaet Y, Mangelsdorff R, Yorou NS, Piepenbring M 2019 - A new species of Pseudocercospora on Encephalartos barteri from Benin. Asian Journal of Mycology 2(1), 101109, Doi 10.5943/ajom/2/1/4

\begin{abstract}
An infection of leaves of Encephalartos barteri (Zamiaceae) by a cercosporoid fungus was repeatedly observed in central Benin, West Africa. Morphological characteristics, the host relationship and DNA sequence data for two gene regions, namely ITS and $r p b 2$, were compared to the corresponding characteristics of closely related, known cercosporoid species and showed that the specimens from Benin represent a new species of Pseudocercospora. Pseudocercospora encephalarti is the first Pseudocercospora species on a species of the host genus Encephalartos, as well as for the whole class Cycadopsida. It was found to be closely associated with a species of Corynespora that could not be identified in the context of the present study.
\end{abstract}

Key words - Corynespora - Cycadopsida - Mycosphaerellaceae - new species - Zamiaceae

\section{Introduction}

The genus Pseudocercospora was established by Spegazzini (1910) based on the type species Pseudocercospora vitis (Lév.) Speg., a foliar pathogen of grapevines. The majority of Pseudocercospora species known to date are pathogens on a wide variety of plants, including numerous economically relevant species of food crops or ornamentals all over the world (Den Breeÿen et al. 2006). They are known mainly from tropical and sub-tropical environments where they cause leaf spots, blight, fruit spots or fruit rot (von Arx 1983, Chupp 1954, Deighton 1976, Pons \& Sutton 1988). Pseudocercospora species are morphologically characterized by pigmented conidia and conidiophores without thickened scars (Pereira \& Barreto 2006). Species of this genus usually infest angiosperms, but a few species are also known from gymnosperms (Braun et al. 2013).

\section{Materials \& Methods}

\section{Collections and morphological studies}

Leaf samples infected by cercosporoid fungi were collected in Benin in July and August of 2016 and 2107. Specimens were observed by stereomicroscopy and by standard methods of light microscopy, using a Zeiss Axioscope 40 microscope. For light microscopy, leaf sections were made 
with razor blades and mounted in distilled water and 5\% $\mathrm{KOH}$ without any staining. Semipermanent preparations of sections of the infected leaf were made by a microtome (Leica CM 1510-1) and mounted in lactophenol with cotton blue. Measurements of 30 conidia, conidiophores and other structures have been made at a magnification of $\times 1000$. Measurements are presented as mean value \pm standard deviation with extreme values in parentheses. For scanning electron microscopy, dried material was directly mounted and sputtered with gold for 3 minutes. Photographs were made with a Hitachi S 4500 scanning electron microscope (SEM).

\section{DNA Extraction and PCR amplification}

DNA was isolated from caespituli taken from dry specimens of the cercosporoid fungus using E.Z.N.A ${ }^{\circledR}$ Forensic DNA Extraction Kit following the manufacturer's instructions with a few modifications. Small pieces of leaves containing several clean caespituli, with as little other fungi as possible, were checked under the stereomicroscope. Precautions were taken to avoid picking any other associated materials that could lead to potential contamination. To extract total genomic DNA from caespituli, a small amount of clean mycelium from the leaf surface was transferred into a sterile Eppendorf tube using a sterilized needle and tape-lifts. The material was homogenized for 710 min. using a Retsch Mixer Mill MM301 with TL buffer and $2.5 \mathrm{~mm}$ Zirconia beads. Isolated DNA was re-suspended in elution buffer and stored at $-20^{\circ} \mathrm{C}$. DNA concentration was checked by a NanoDrop 2000c spectrophotometer (Thermo Fisher Scientific, USA).

Two genomic loci were amplified. For the ITS region, primers V9G (de Hoog \& Gerrits van den Ende 1998) with ITS4 (White et al. 1990) and for the rpb2-locus Rpb2-F4 (Videira et al. 2017) or RPB2-5F2 (Sung et al. 2007) with fRPB2-7cR (Liu et al. 1999) were used. PCR amplification and sequencing were conducted following the protocols of Crous et al. $(2009,2012)$ and Videira et al. (2017). The PCR mixtures consisted of $1 \mu \mathrm{L}$ genomic DNA, $15 \times \mathrm{MgCl}_{2}$ reaction buffer (Bioline, Luckenwalde, Germany), $25 \mathrm{mM} \mathrm{MgCl}_{2}, 25 \mu \mathrm{M}$ of each dNTP, $10 \mu \mathrm{M}$ of each primer and $5 \mathrm{U}$ Taq DNA polymerase (VWR) in a total volume of $25 \mu \mathrm{L}$. Cycling parameters of the PCR for ITS were as follows: initial denaturation $94^{\circ} \mathrm{C}$ for $3 \mathrm{~min} ; 35$ cycles of amplification [denaturation at $94^{\circ} \mathrm{C}$ for $30 \mathrm{~s}$, primer annealing $52^{\circ} \mathrm{C}$ for $30 \mathrm{~s}$ and TAQ extension $72^{\circ} \mathrm{C}$ for $45 \mathrm{~s}$, and a final TAQ extension $72^{\circ} \mathrm{C}$ for $5 \mathrm{~min}$, followed by storage at $8^{\circ} \mathrm{C}$. The PCR mixture for $r p b 2$ contained $2 \mu \mathrm{L}$ of template DNA and to obtain the partial $r p b 2$, a touchdown PCR protocol was used as described by Videira et al. (2017). PCR-products were checked on $1.5 \%$ agarose electrophoresis gels containing HDGreenPlus DNA stain. Amplified PCR products were purified with the Cycle Pure Kit (VWR-Omega, USA). Sequencing was performed at Seqlab GmbH, Germany.

\section{Molecular phylogeny}

Amplification of the ITS and $r p b 2$ gene regions for all isolates used in this study resulted in amplification products of approximately $650 \mathrm{bp}$ for ITS and $1068 \mathrm{bp}$ for $r p b 2$. Consensus sequences of trace files were generated with Geneious 10.2.2 (https://www.geneious.com, Kearse et al. 2012) and searched against GenBank (https://www.ncbi.nlm.nih.gov/, Benson et al. 2013) with MegaBLAST. Sequences with a maximum identity of more than 95\% (14 sequences to ITS and rpb2) were retrieved (Table 1). The sequences obtained from GenBank (Table 1) and sequences generated in this study were aligned with MAFFT v. 7 using the L-INS-i algorithm, (Nakamura et al. 2018). The alignments were manually checked by using MEGA v. 7 (Kumar et al. 2016). Gblocks v. 0.91b (Talavera \& Castresana 2007) was used to remove poorly aligned positions and divergent regions from the DNA alignment using the parameters for a less stringent selection. To test the level of congruence among the two loci (ITS \& rpb2), the Congruence Among Distance Matrices test, CADM global of R package APE v.3.2 (Paradis et al. 2004, R Core Team 2017), was performed. The CADM results showed that the null hypothesis of complete incongruence among loci was rejected $(\mathrm{W}=0.0 .89 ; \mathrm{p}<0.01$ ), thus allowing concatenation of the two loci. Subsequently a two locus concatenated alignment (ITS, rpb2) dataset using Geneious 10.2.2 for phylogenetic analyses was assembled. Passalora eucalypti (CBS 111318) served as outgroup taxon as proposed 
by Crous et al. (2012). PartitionFinder2 XSEDE v.2.1.1 (Miller et al. 2010) was used to select the best-fit model of evolution ( $\mathrm{K} 80+\mathrm{I}+\mathrm{G}$ model to ITS, and $\mathrm{K} 80+\mathrm{I}$ model to $r p b 2$ ) for each gene fragment separately for Bayesian and Maximum Likelihood (ML) analyses. The alignment and the tree were deposited in TreeBASE (http://purl.org/phylo/treebase/phylows/study/TB2:S23598). Phylogenetic analyses of this study were conducted by applying Maximum Likelihood (ML) with RAxML-HPC2 on XSEDE v.8.2.10 (Miller et al. 2010) and Bayesian with MrBayes on XSEDE v.3.2.6 (Miller et al. 2010) methods in the CIPRES Science Gateway web portal. (http://www.phylo.org/sub_sections/portal/). For Maximum Likelihood phylogenies performed with RAxML 1000 rapid bootstrap inferences were executed. For Bayesian phylogenies, two parallel runs with eight chains of Metropolis-coupled Markov chain Monte Carlo iterations were performed with the heat parameter being set at 0.2. Analyses were run for 100 million generations, with trees sampled every 1000th generation until the average standard deviation of split frequencies reached 0.01 (stop value). The first $25 \%$ of saved trees were discarded as the 'burn-in' phase. Posterior probabilities (PP) were determined from the remaining trees. Bayesian posterior probabilities (BPP) $\geq 94 \%$ and Bootstrap values (BS) $\geq 70 \%$ were considered significant.

Table 1 Sequences downloaded from GenBank (in alphabetical order) used in this study

\begin{tabular}{|c|c|c|c|c|c|}
\hline \multirow[t]{2}{*}{ Species } & \multirow[t]{2}{*}{ Host } & \multirow[t]{2}{*}{ Sources } & \multicolumn{2}{|c|}{ GenBank Accession No. } & \multirow[t]{2}{*}{ References } \\
\hline & & & ITS & $r p b 2$ & \\
\hline Passalora eucalypti & $\begin{array}{l}\text { Eucalyptus } \\
\text { saligna }\end{array}$ & CBS 111318 & KF901613 & KF902267 & $\begin{array}{l}\text { Quaedvlieg et al. } \\
2014\end{array}$ \\
\hline $\begin{array}{l}\text { Pseudocercospora } \\
\text { breonadiae }\end{array}$ & $\begin{array}{l}\text { Breonadia } \\
\text { salicina }\end{array}$ & CBS 143489 & MH107913 & MH108006 & Crous et al. 2018 \\
\hline $\begin{array}{l}\text { Pseudocercospora } \\
\text { catappae }\end{array}$ & $\begin{array}{l}\text { Terminalia } \\
\text { catappa }\end{array}$ & $\begin{array}{l}\text { MAFF } \\
238312\end{array}$ & MF951366 & MF951616 & Videira et al. 2017 \\
\hline $\begin{array}{l}\text { Pseudocercospora } \\
\text { dingleyae }\end{array}$ & Haloragis erecta & CBS 114645 & KX287299 & KX288454 & Videira et al. 2016 \\
\hline $\begin{array}{l}\text { Pseudocercospora } \\
\text { flavomarginata }\end{array}$ & $\begin{array}{l}\text { Eucalyptus } \\
\text { camaldulensis }\end{array}$ & CBS 124990 & GU269799 & MF951619 & Videira et al. 2016 \\
\hline $\begin{array}{l}\text { Pseudocercospora } \\
\text { madagascariensis }\end{array}$ & $\begin{array}{l}\text { Eucalyptus } \\
\text { camaldulensis }\end{array}$ & CBS 124155 & KF901673 & KF902318 & $\begin{array}{l}\text { Quaedvlieg et al. } \\
2014\end{array}$ \\
\hline $\begin{array}{l}\text { Pseudocercospora } \\
\text { nelumbonicola }\end{array}$ & $\begin{array}{l}\text { Nelumbo } \\
\text { nucifera }\end{array}$ & $\begin{array}{l}\text { Kirschner } \\
4111\end{array}$ & KY304492 & LC199940 & $\begin{array}{l}\text { Chen \& Kirschner } \\
2018\end{array}$ \\
\hline $\begin{array}{l}\text { Pseudocercospora } \\
\text { neriicola }\end{array}$ & Nerium oleander & CBS 138010 & NR137885 & KX462647 & $\begin{array}{l}\text { Nakashima et al. } \\
2016\end{array}$ \\
\hline $\begin{array}{l}\text { Pseudocercospora } \\
\text { prunicola }\end{array}$ & $\begin{array}{l}\text { Prunus } \\
\text { yedoensis }\end{array}$ & CBS 132107 & GU269676 & MF951621 & Videira et al. 2016 \\
\hline $\begin{array}{l}\text { Pseudocercospora } \\
\text { sp. }\end{array}$ & $\begin{array}{l}\text { Syzygium } \\
\text { cordatum }\end{array}$ & CBS 110780 & KX287305 & KX288461 & Videira et al. 2016 \\
\hline $\begin{array}{l}\text { Pseudocercospora } \\
\text { sp. }\end{array}$ & $\begin{array}{l}\text { Eichhornia } \\
\text { azurea }\end{array}$ & СРC 19535 & KX287303 & KX288458 & Videira et al. 2016 \\
\hline $\begin{array}{l}\text { Pseudocercospora } \\
\text { sp. }\end{array}$ & Eichornia azurea & CPC 19537 & KX287304 & KX288460 & Videira et al. 2016 \\
\hline $\begin{array}{l}\text { Pseudocercospora } \\
\text { sp. }\end{array}$ & $\begin{array}{l}\text { Chromolaena } \\
\text { odorata }\end{array}$ & CBS 113386 & DQ676532 & KX288459 & Videira et al. 2016 \\
\hline $\begin{array}{l}\text { Pseudocercospora } \\
\text { tereticornis }\end{array}$ & $\begin{array}{l}\text { Eucalyptus } \\
\text { tereticornis }\end{array}$ & CPC 13008 & KF901531 & KF902335 & $\begin{array}{l}\text { Quaedvlieg et al. } \\
2014\end{array}$ \\
\hline
\end{tabular}

\section{Results}

\section{Phylogenetic analyses}

A combined analysis of ITS and $r p b 2$ sequence data was performed to resolve the phylogenetic position of isolates taken from a species of Pseudocercospora on leaves of 
Encephalartos barteri among known species of the Pseudocercospora selected from GenBank (Table 1).

For the species level analysis, DNA sequence data from the ITS and rpb2 gene regions were combined for the Bayesian and Maximum Likelihood analyses. The concatenated alignment contained a total of 15 sequences including the out-group (14 sequences from NCBI and one sequence from this study). As the likelihood analyses produced tree topologies mostly identical to results of Bayesian analyses, bootstrap support values of the likelihood trees were incorporated into the tree that resulted from Bayesian analyses (Fig. 1). The sequence data of the Pseudocercospora species from Benin are placed in a sub-clade together with combined sequence data of $P$. breonadiae, $P$. neriicola and P. madagascariensis, Pseudocercospora sp. (CPC19537) and Pseudocercospora sp. (CPC19535) (Fig. 1) which is confirmed by the Maximum parsimony analysis of the combined ITS and $r p b 2$ alignment (tree not presented here). Rpb2 sequence data showed differences between closely related species in the genus Pseudocercospora and are therefore more informative than the ITS data. Based on a megablast search using the rpb2 sequence-data of the new species from Benin, the closest matches in NCBI's GenBank nucleotide database were Pseudocercospora sp. CPC 19535 (GenBank KX288458; identities = 827/848, i.e., $98 \%$ ), and P. breonadiae (GenBank MH108006; identities $=775 / 790$, i.e., $98 \%$ ).

The infection of leaves of Encephalartos barteri by Pseudocercospora sp. was frequently associated with infection by Corynespora sp. (Fig. 4), for which an ITS sequence including 680 bp (YMMB78, GenBank MK402156) was obtained. A BLAST search based on this ITS sequence yielded most similar sequences of Corynespora species with a homology of less than 95\%, namely of $C$. smithii (GenBank KY984300) and C. citricola (GenBank FJ852593).

\section{Taxonomy}

Pseudocercospora encephalarti Y. Meswaet, Mangelsdorff, Yorou \& M. Piepenbr. sp. nov.

Index Fungorum number: IF555815; Facesoffungi number: FoF06035

Etymology - based on the host genus from which it was collected.

Leaf spots almost lacking or yellowish to brownish discolorations, 1.7-9 mm diam., margin indefinite. Caespituli epigenous, punctiform, dense, grayish brown to medium brown. Mycelium internal and external. Internal hyphae branched, 2.5-4.5 $\mu \mathrm{m}$ wide, septate, olivaceous brown to slightly dark brown. Stromata well-developed, immersed in the epidermis or in stomata and substomatal chambers, globular to irregular, 20-50 $\mu \mathrm{m}$ diam., brown to dark brown. Conidiophores in large fascicles of more than ten, arising from stromata, breaking through the adaxial epidermis of the leaves or penetrating through stomata, rarely solitary and arising from external hyphae, straight to bent or sinuous, rarely geniculate, slightly wider and rounded towards the apex, rarely branched, (14-)22-45.5(-68) × 3-4.5 $\mu \mathrm{m}, 1-3$-septate, thin-walled, smooth, brown to dark brown, uniform in color. Conidiogenous loci unthickened and not darkened, 1-2 $\mu \mathrm{m}$ wide. Conidia solitary, narrowly obclavate to subacicular, straight to curved, $(55-) 90-167.5(-190) \times 3.5-4.5(-5) \mu \mathrm{m}, 3-8$-septate, pale olivaceous to olivaceous brown, thin-walled, smooth, apex subacute, base truncate to obconically truncate, hila unthickened, not darkened, $1.5 \mu \mathrm{m}$ wide (Figs 2, 3, 4).

Material examined - Benin, Department Borgou, Commune Tchaourou, Reserve Forest of Wari-Maro, ca. $248 \mathrm{~m}$ a.s.1., 908"37,38' N, 207"57,58' E, on leaves of Encephalartos barteri Carruth. ex Miq. (Zamiaceae), 04 August 2017, Meswaet Y, Piepenbring M, Yorou NS \& members of 2017 summer school students in West Africa YMMA78 (M-0141346 holotype; BENIN, UNIPAR, ETH isotypes).

Additional material examined - Benin, Department Borgou, Commune Tchaourou, Reserve forest of Wari-Maro, ca. $248 \mathrm{~m}$ a.s.1., $9^{\circ} 08^{\prime \prime} 37,38^{\prime} \mathrm{N}, 2^{\circ} 07^{\prime \prime} 57,58^{\prime} \mathrm{E}$, on leaves of Encephalartos barteri Carruth. ex Miq. (Zamiaceae), 08 August 2016, Mangelsdorff R, Meswaet Y, Piepenbring M, Yorou NS \& members of 2016 summer school students in West Africa YMMA23 (M-0141347 paratype). 
Corynespora sp. on Encephalartos barteri

Leaf spots absent or large pale brown irregular leaf discoloration, 2-9 $\mathrm{mm}$ diam., margin indefinite. Caespituli amphigenous, velvety or spongy, forming small to widely effused patches, dark brown to black. Mycelium internal and external. Internal hyphae, branched, 2.5-3.5 $\mu \mathrm{m}$ wide, septate, olivaceous brown to slightly dark brown. Stromatawell-developed, partly superficial, partly immersed in the epidermis, globular to irregular, thick, $15-45(-65) \mu \mathrm{m}$ in diam., brown to dark brown. Conidiophores in fascicles, arising from stromata, and solitary, arising from external hyphae, erect straight to slightly flexuous, with up to four proliferations, branched (30-)48-167($180) \times(4-) 4.5-5(-5.5) \mu \mathrm{m}, 2-7$ septate, brown to dark brown, uniform in color. Conidiogenous loci brown. Conidia solitary, broadly obclavate to subacicular, $(35-) 56.5-180(-198) \times 3.5-4.5(-5)$ $\mu \mathrm{m}$, multi-septate, olivaceous brown to slightly dark brown, thick-walled, smooth, apex subacute, base truncate to obconically truncate, hila, unthickened.

Material examined: Benin, Department Borgou, Commune Tchaourou, Wari-Maro, ca. $248 \mathrm{~m}$ a.s.1., 9 $9^{\circ} 08^{\prime \prime} 37,38^{\prime} \mathrm{N}, 2^{\circ} 07^{\prime \prime} 57,58^{\prime} \mathrm{E}$, on living leaves of Encephalartos barteri Carruth. ex Miq. (Zamiaceae), 04 August 2017, Meswaet Y, Piepenbring M, Yorou NS \& members of 2017 summer school students in West Africa YMMB78 (M-0141346).

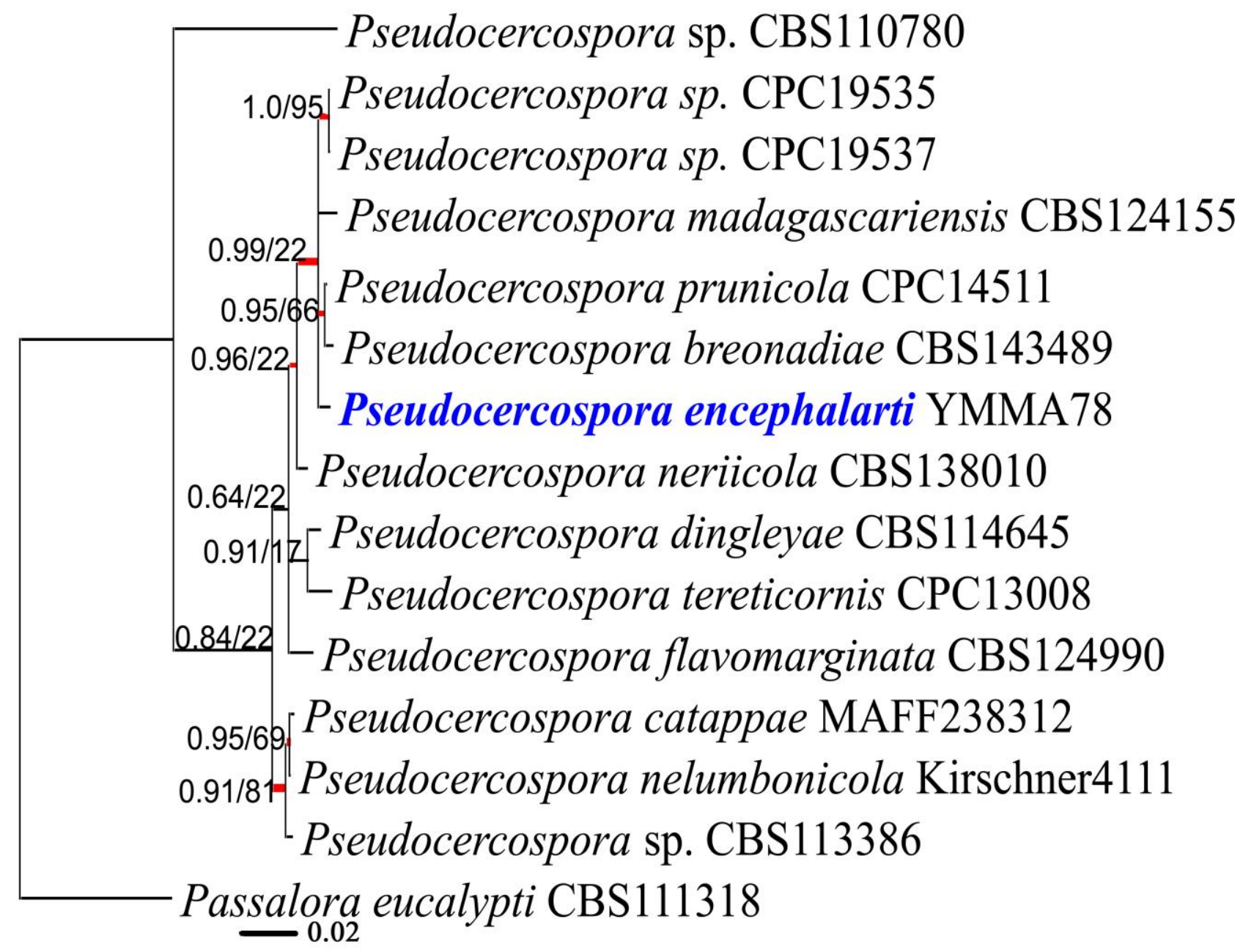

Fig. 1 - The Bayesian phylogenetic tree inferred from DNA sequence data from the multigene alignment (ITS and rpb2) of cercosporoid species. The newly detected species is indicated in blue color and nodes receiving Bayesian PP $\geq 0.94$ or ML bp $\geq 70 \%$ are considered as strongly supported and are indicated by thickened red branches. 

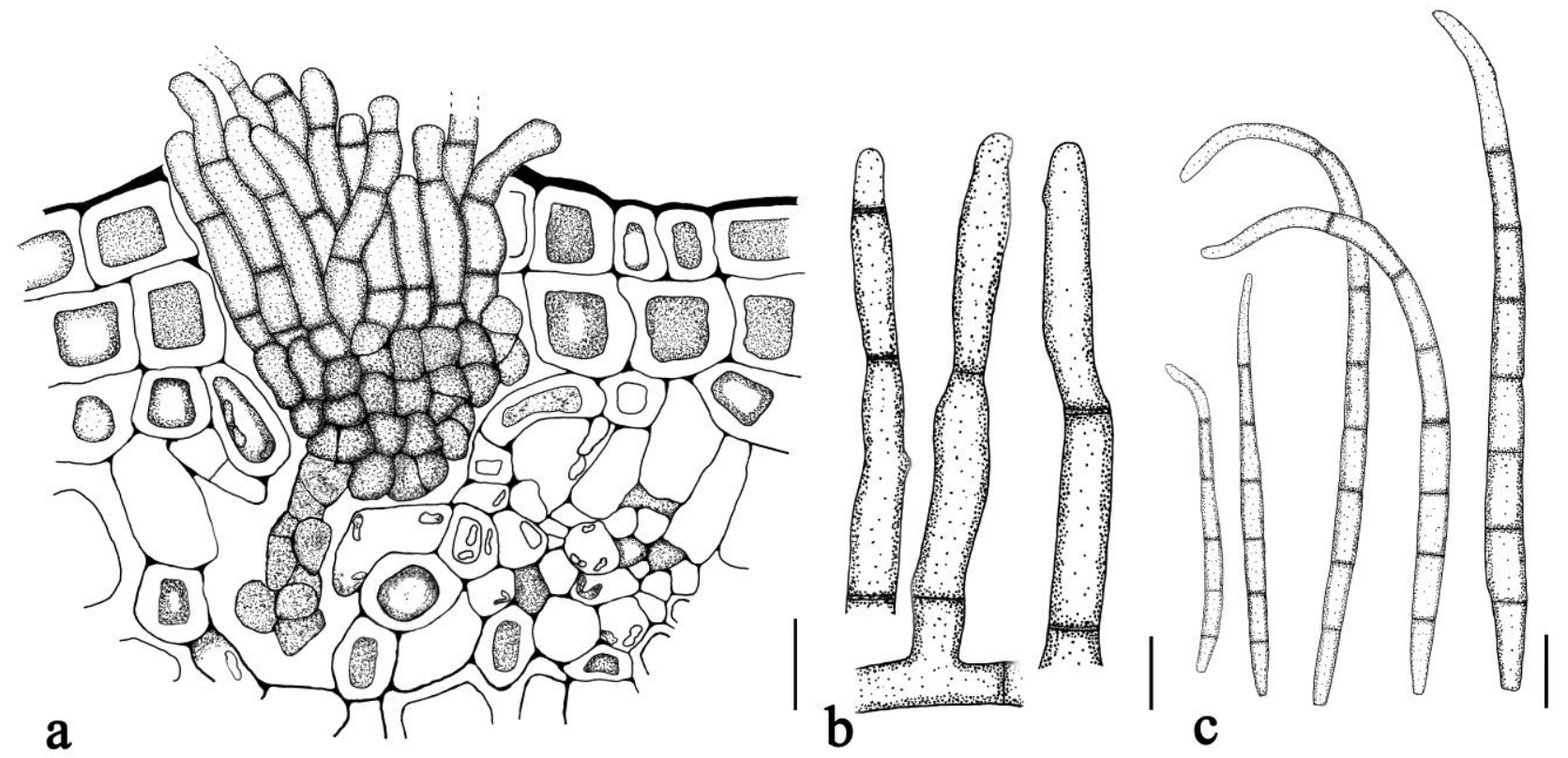

Fig. 2 - Line drawings of Pseudocercospora encephalarti (YMMA78). a Well-developed, immersed stroma with conidiophores. b Solitary conidiophores arising from external hyphae. c Conidia. Scale Bars: $\mathrm{a}=20 \mu \mathrm{m}, \mathrm{b}$ and $\mathrm{c}=10 \mu \mathrm{m}$.

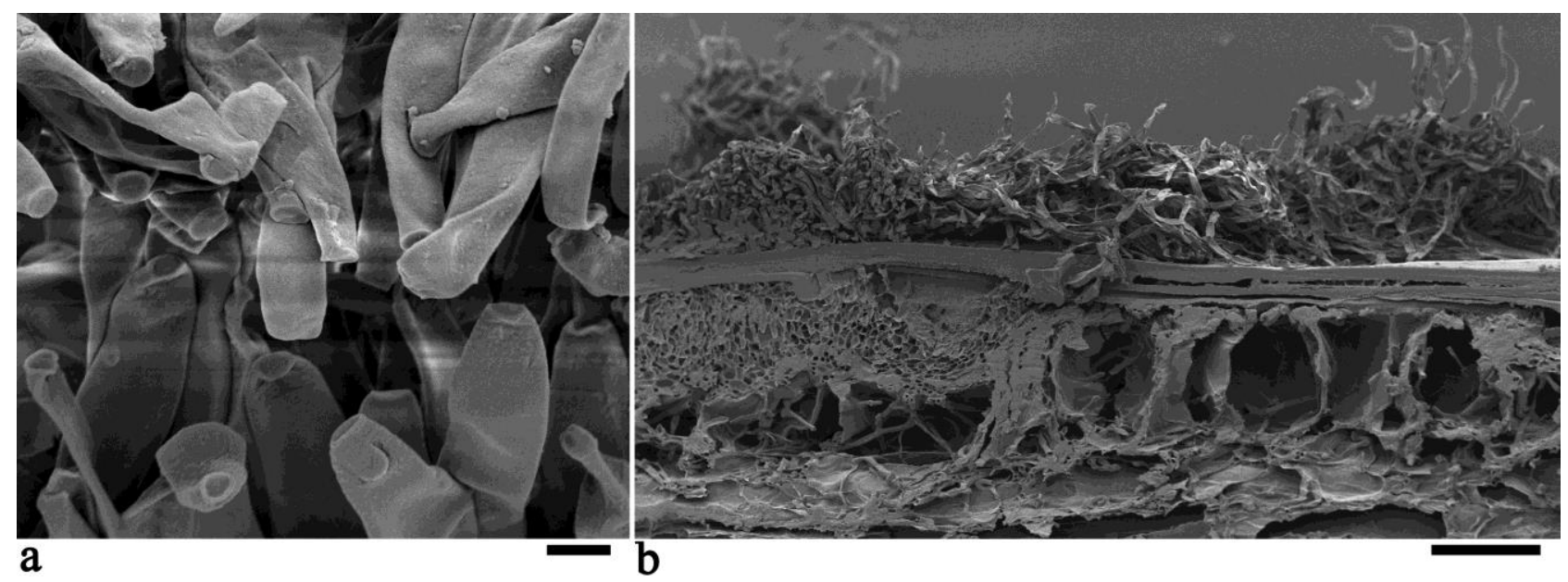

Fig. 3 - Pseudocercospora encephalarti on leaf tissue of Encephalartos barteri as seen by scanning electron microscopy (YMMA78). a Conidiophores with 1-2 flat conidiogenous loci without particular structures. b Leaf tissue with internal hyphae and superficial fungal cells (conidiophores and conidia). Scale Bars: $\mathrm{a}=10 \mu \mathrm{m}, \mathrm{b}=200 \mu \mathrm{m}$.

\section{Discussion}

Pseudocercospora species usually have unthickened and not darkened conidiogenous loci and conidial hila, while conidiophores as well as conidia are pigmented (Deighton 1976, Pereira \& Barreto 2006). On account of these characteristics the specimens from Benin belong to the genus Pseudocercospora which is also confirmed by molecular data. Except for two unnamed Pseudocercospora spp. reported from Encephalartos spp. in South Africa (Nesamari et al. 2017), no Pseudocercospora species on hosts belonging to Cycadopsida are known up to now. For the whole group of cercosporoid fungi, the presented Pseudocercospora species is the first species on a host of the genus Encephalartos. According to Nesamari et al. (2017), the two Pseudocercospora species reported from South Africa [Pseudocercospora sp. 1 (CMW44333) on Encephalartos ferox 
and Pseudocercospora sp. 2 (CMW44983) on Encephalartos villosus] are closely related to each other and to Pseudocercospora acericola, Pseudocercospora lythracearum, Pseudocercospora crispans and Pseudocercospora rubi, taxa that are not closely related to the species included in the present analysis (Fig. 1). According to the authors, the systematic relationships of the Pseudocercospora spp. from South Africa were evident by analyses of sequence data of the gene regions ITS, ACT, TEF-1a. The two Pseudocercospora species on Encephalartos hosts in Nesamuri et al. (2017), however, were mentioned without names, morphological characteristics, or molecular sequence data in GenBank, and could, therefore, not be directly compared to the specimens from Benin. On account of the presented multi-locus phylogenetic analyses as presented in Fig. 1, all five species in the clade of the new Pseudocerspora species from Benin are closely related to each other. Most Pseudocercospora species are host-specific with a host range limited to a single plant genus or related genera within a family (Nakashima et al. 2016). Thus, $P$. encephalarti is described as a new species, characterized by epigenous caespituli without showing any distinct leaf spots or with yellowish to brownish discolorations (Fig. 4), having well-developed stromata (Fig. 2a), relatively long and wide conidia and conidiophores (Fig. 2b-c), as well as internal and external hyphae (Fig. 3). Encephalartos barteri is an indigenous plant known in the four West African countries of Benin, Ghana, Nigeria and Togo (Akoégninou et al. 2006), where fungal biodiversity has been poorly studied as in many African countries. It therefore is not surprising that the described new Pseudocercospora species has not yet been reported.

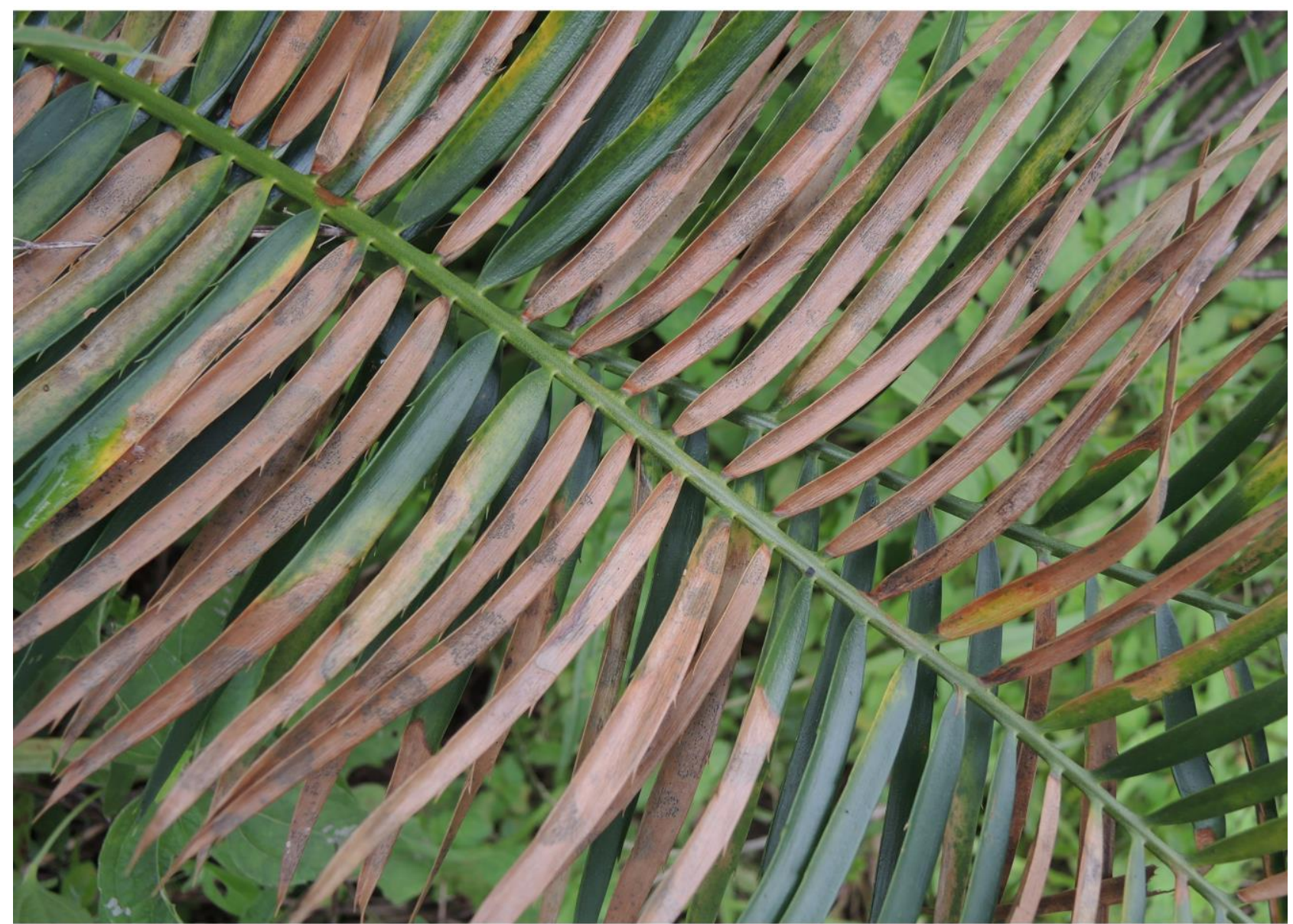

Fig. 4 - A leaf of Encephalartos barteri showing brown discoloration caused by Corynespora sp., partly associated with Pseudocercospora encephalarti (YMMB78).

For the genus Corynespora, approximately 200 species are established, often mainly based on new host plant species. A critical revision of the genus is lacking. For some species of Corynespora DNA sequence data are available and show a maximum similarity to the sequence obtained from 
the specimen from Benin of 95 percent. As long as further data on established Corynespora spp. are not available, a reliable species identification is not possible and we refrain from establishing a new species for the specimens from Benin.

\section{Acknowledgements}

We are grateful to Niklas Döring at Gothe-Universität Frankfurt am Main for making scanning electron microscope photographs. Our special thanks go to Roland Kirschner, Hermine Lotz-Winter, José Macia-Vicente, and Kai Reschke for fruitful discussions and valuable advice for improving the manuscript and the molecular phylogeny. Afoussathou Tabe (Faculty of Agronomy, University of Parakou, Benin) assisted in specimen sampling in the field. Our participation to the 2016 and 2017 summer schools in tropical mycology in Benin, along with the field works, have been possible through a financial support by the Volkswagen Foundation and the Freunde und Förderer der Goethe-Universität. A special gratitude goes to the Adolf Messer Foundation for providing a scholarship to the first author.

\section{References}

Akoégninou A, van der Burg WJ, van der Maesen LJG. 2006 - Flore analytique du Bénin. In: Adjakidj`e V, Essou JP, Sinsin B, Yédomonhan H (eds), Backhuys Publishers 22-23. Université d'Abomey-Calavi, Cotonou, Benin.

Arx JA von. 1983 - Mycosphaerella and its anamorphs. Proceedings of the Koninklijke Nederlandse Akademie van Wettenschappen, Series C 86, 15-54.

Benson DA, Cavanaugh M, Clark K, Karsch-Mizrachi I et al. 2013 - GenBank. Nucleic acids research, 41(D1), D36-D42.

Braun U, Nakashima C, Crous PW. 2013 - Cercosporoid fungi (Mycosphaerellaceae). 1. Species on other fungi, Pteridophyta and Gymnospermae. IMA Fungus 4, 265-345.

Chupp C. 1954 - A monograph of the fungus genus Cercospora. Published by the author, Ithaca, New York.

Chen KL, Kirschner R. 2018 - Fungi from leaves of lotus (Nelumbo nucifera). Mycological Progress 17, 275-293.

Crous PW, Braun U, Hunter GC, Wingield MJ et al. 2012 - Phylogenetic lineages in Pseudocercospora. Studies in Mycology 75, 37-114.

Crous PW, Schoch CL, Hyde KD, Wood AR, Gueidan C, de Hoog GS. 2009 - Phylogenetic lineages in the Capnodiales. Studies in Mycology 64, 17-47.

Crous PW, Schumacher RK, Wingfield MJ, Akulov A et al. 2018 - New and Interesting Fungi. 1. Fungal Systematics and Evolution 1, 169-215.

Deighton FC. 1976 - Studies on Cercospora and allied genera.VI. Pseudocercospora Speg., Pantospora Cif. and Cercoseptoria Petr. Mycological Papers 140, 1-168.

Den Breeÿen A, Groenewald JZ, Verkley GJM, Crous PW. 2006 - Morphological and molecular characterisation of Mycosphaerellaceae associated with the invasive weed, Chromolaena odorata. Fungal Diversity 23, 89-110.

Hoog GS de, Gerrits van den Ende AHG. 1998 - Molecular diagnostics of clinical strains of filamentous Basidiomycetes. Mycoses 41, 183-189.

Kearse M, Moir R, Wilson A, Stones-Havas S, et al. 2012 - Geneious basic: an integrated and extendable desktop software platform for the organization and analysis of sequence data. Bioinformatics 28, 1647-1649.

Kumar S, Stecher G, Tamura K. 2016 - MEGA Molecular Evolutionary Genetics Analysis Version 7.0: For Bigger Datasets. Molecular Biology and Evolution 33, 1870-1874.

Liu YJ, Whelen S, Hall BD. 1999 - Phylogenetic relationships among ascomycetes: evidence from an RNA polymerase II subunit. Molecular Biology and Evolution 16, 1799-1808.

Miller MA, Pfeiffer W, Schwartz T. 2010 - Creating the CIPRES Science Gateway for inference of large phylogenetic trees. Gateway Computing Environments Workshop (GCE), IEEE: 1-8. 
Nakamura T, Yamada KD, Tomii K, Katoh K. 2018 - Parallelization of MAFFT for large scale multiple sequence alignments. (describes MPI parallelization of accurate progressive options). Bioinformatics 34, 2490-2492.

Nakashima C, Motohashi K, Chen CY, Groenewald JZ, Crous PW. 2016 - Species diversity of Pseudocercospora from Far East Asia. Mycological Progress 15, 1093-1117.

Nesamari R, Coutinhoa TA, Rouxb J. 2017 - Investigations into Encephalartos insect pests and diseases in South Africa and identification of Phytophthora cinnamomi as a pathogen of the Modjadji cycad. Plant Pathology 66, 612-622.

Paradis E, Paradis J, Strimmer K. 2004 - APE: analyses of phylogenetics and evolution in R language. Bioinformatics 20, 289-290.

Pereira OL, Barreto RW. 2006 - Pseudocercospora palicoureae sp. nov. associated with the toxic rubiaceous weed Palicourea marcgravii in Brazil, with observations on its mycobiota. Fungal Diversity 23, 243-253.

Pons N, Sutton BC. 1988 - Cercospora and similar fungi on Yams (Dioscorea species). Mycological Papers 160, 1-78.

Quaedvlieg W, Binder M, Groenewald JZ, Summerell BA et al. 2014 - Introducing the Consolidated Species Concept to resolve species in the Teratosphaeriaceae. Persoonia 33, 140.

R Core Team 2017 - R: A Language and Environment for Statistical Computing. R Foundation for Statistical Computing Vienna, Austria.

Spegazzini C. 1910 - "Mycetes Argentinenses (Series V)". Anales del Museo Nacional de Historia Natural, Buenos Aires 20, 329-467.

Sung GH, Sung JM, Hywel-Jones NL, Spatafora JW. 2007 - A multigene phylogeny of Clavicipitaceae (Ascomycota, Fungi): identification of localized incongruence using a combinational bootstrap approach. Molecular Phylogenetics and Evolution 44, 1204-1223.

Talavera G, Castresana J. 2007 - Improvement of phylogenies after removing divergent and ambiguously aligned blocks from protein sequence alignments. Systematic Biology 56, 564577.

Videira SIR, Groenewald JZ, Braun U, Shin HD, Crous PW. 2016 - All that glitters is not Ramularia. Studies in Mycology 83, 49-163.

Videira SIR, Groenewald JZ, Nakashima C, Braun U et al. 2017 - Mycosphaerellaceae - chaos or clarity? Studies Mycology 87, 257-421.

White TJ, Bruns T, Lee S, Taylor J. 1990 - Amplification and direct sequencing of fungal ribosomal RNA genes for phylogenetics. In: Innis MA, Gelfand DH, Sninsky JJ, White TJ 268 (eds), PCR Protocols: a guide to methods and applications. Academic Press, New York 315-322. 